IZA DP No. 8486

Female Self-Employment and Children:

The Case of Sweden

Pernilla Andersson Joona

September 2014 


\title{
Female Self-Employment and Children: The Case of Sweden
}

\author{
Pernilla Andersson Joona \\ SOFI, Stockholm University \\ and IZA
}

\author{
Discussion Paper No. 8486 \\ September 2014
}

\author{
IZA \\ P.O. Box 7240 \\ 53072 Bonn \\ Germany \\ Phone: +49-228-3894-0 \\ Fax: +49-228-3894-180 \\ E-mail: iza@iza.org
}

Any opinions expressed here are those of the author(s) and not those of IZA. Research published in this series may include views on policy, but the institute itself takes no institutional policy positions. The IZA research network is committed to the IZA Guiding Principles of Research Integrity.

The Institute for the Study of Labor (IZA) in Bonn is a local and virtual international research center and a place of communication between science, politics and business. IZA is an independent nonprofit organization supported by Deutsche Post Foundation. The center is associated with the University of Bonn and offers a stimulating research environment through its international network, workshops and conferences, data service, project support, research visits and doctoral program. IZA engages in (i) original and internationally competitive research in all fields of labor economics, (ii) development of policy concepts, and (iii) dissemination of research results and concepts to the interested public.

IZA Discussion Papers often represent preliminary work and are circulated to encourage discussion. Citation of such a paper should account for its provisional character. A revised version may be available directly from the author. 


\section{ABSTRACT}

\section{Female Self-Employment and Children: The Case of Sweden}

Previous studies, mostly from Anglo-Saxon countries, find a positive correlation between the presence of young children in the household and self-employment probabilities among women. This has been seen as an indication of women with young children choosing selfemployment as a way of balancing work and family commitments. This paper studies the relationship between children and female self-employment in a country with family friendly policies and a generous welfare system: Sweden. The initial hypothesis is that we will not find evidence of a positive effect of children on self-employment among Swedish women since there are other institutions in place aiming at facilitating the combination of work and family. Using Swedish register data for the period 2004-2008 we do, however, find that the presence of young children increases the probability of choosing self-employment also among Swedish women. The effect is strongest for women with very young children, 0-3 years of age. These results also hold in a panel data model that takes individual unobserved heterogeneity into account. We also analyze time-use data and find, contrary to what has been found in many other countries, that self-employed women spend more, or as much, time on market work than wage-earning women. This raises doubts about whether women in Sweden chose selfemployment as a way of balancing work and family commitments. We suggest an alternative interpretation which is that women who chose self-employment while the children are young in fact are women with strong preferences for market work.

JEL Classification: J22, L26, J13

Keywords: $\quad$ work, family, self-employment, fertility

Corresponding author:

Pernilla Andersson Joona

Swedish Institute for social research (SOFI)

Stockholm University

S-106 91 Stockholm

Sweden

E-mail: Pernilla.andersson.joona@sofi.su.se

* The author gratefully acknowledges financial support from the Swedish Research Council (VR). 


\section{Introduction}

It has been argued that women choose self-employment as a way of balancing work and family commitments, in particular if there are young children living in the household. The presence of children increases the amount of household work at the same time as the parents' demand for flexible scheduling increases. Self-employment is assumed to increase flexibility regarding when and where the work is performed and self-employment also involves a higher degree of control and self-determination than what wage-earning employment does. Previous studies, mostly from Anglo-Saxon countries, find a positive correlation between the presence of young children in the household and self-employment probabilities among women (Boden 1996; Budig 2006; Hundley 2000; Lombard 2001; Wellington 2006). This has been interpreted as evidence of women choosing self-employment as a way of balancing work and family commitments. Boden (1999) using survey data from the US, report that in particular women with young children are more likely than men to state that they become self-employed to increase flexibility and for family related reasons. This is also in line with the findings of Carr (1996). Related studies using timeuse data find that self-employed women spend more time on household work than wage earning women and less time on market work (Gurley-Calvez et al. 2009; Craig et al. 2014).

There are no previous studies investigating this hypothesis for Sweden where the labor market is structured in a very different way than, for example, in the US. There are reasons to believe that Swedish women do not choose self-employment in order to achieve more flexibility and to facilitate the combination of work and family; there are other institutions in place in the Swedish labor market aimed at facilitating the combination of work and family for parents with young children: large scale publically subsidized child care, a generous parental leave system with built-in incentives for fathers to take more parental leave ${ }^{1}$, and the right for parents with children up to eight years to work part-time. Looking at the Swedish labor market in an international comparison we see that female self-employment rates are low while female labor force participation is high, part-time work is high, and fertility levels are high. Taken together, it seems plausible that Swedish women manage to combine work and family without choosing selfemployment to a very high extent. Rønsen (2014) has a similar discussion about the relationship

\footnotetext{
${ }^{1}$ Examples of this are two so called "daddy-months" that cannot be transferred to the mother, a higher replacement rate than in the public health insurance, and a bonus paid to couples who share their parental leave equally.
} 
between children and self-employment among Norwegian women: the extra working time associated with being self-employed should outweigh the flexibility and self-autonomy associated with being self-employed in a welfare-state, such as Norway, with a good supply of state-sponsored child care. Rønsen (2014) does, however, find indications of a positive association between the presence of young children (up to eleven years of age) and female selfemployment also in Norway. Using survey data with information on working hours, she also reports that self-employed women on average spend more time on market work than wageearning women do.

In this paper I use Swedish register data for the total Swedish population covering the period 2004-2008 and estimate both pooled cross sectional models and fixed effect models to analyze the effect of young children in the household on self-employment probabilities. I find that the presence of young children increases the probability of choosing self-employment also among Swedish women. The effect is found to be strongest for women with very young children, 0-3 years of age and the effect is decreasing with the age of the children. I also find a positive effect of having children on self-employment probabilities for men but here the effect is strongest for the presence of slightly older children (7-10 years).

To interpret these results I relate the findings to what we know about how self-employed and wage-earners divide their time between market- and household work. If women choose selfemployment as a way of balancing work and family commitments we would expect that they spend less time on market work and more time on household work compared to wage-earning women. Hundley (2000) provides us with an explanation for why this should be the case. He argues that self-employment are not subject to some of the constraints of organizational employment; he assumes that there is a lower bound defined by the minimum contribution of the worker in organizational employment and an upper bound defined by the ability of organizations of rewarding very skilled employees. Due to the lack of primarily the lower bound in selfemployment, it will be easier for the self-employed to adjust their time spent on market and household work if family responsibilities increase. Having the US labor market in mind, he further argues that self-employed women will work fewer market hours and more housework hours compared to their organizational counterparts while the opposite will be true for selfemployed men. 
In this paper an alternative explanation for the results which has been given far less attention in self-employment literature is suggested: mothers of young children who choose self-employment are in fact women who have very strong preferences for market work and are career oriented. Becoming a mother in Sweden is associated with expectations of that she will leave the labor market a fairly long time due to the generous parental leave system; it is possible to be a way from work and to receive parental leave benefits for up to one and a half year. At the same time, differences in parental leave periods between mothers and fathers are assumed to be one of the main explanations for the persistent gender wage gap on the Swedish labor market. For women who are career oriented, self-employment might be an alternative if one wants to work while the children are very young or do not want to reduce the working time as much as one perhaps would have needed to do if one would have been employed as a wage-earner. Few employers may have such flexibility in their organization which makes it possible for mothers (or fathers) with very young children to decide entirely on their own when to work and how much work to perform. Previous studies for Sweden and several different data sources which include information about how workers divide their time between market- and household work, show that self-employed women in Sweden spend more, or as much, time on market work than wageearning women and there are no significant differences in the amount of time spent on household work. This raises doubts about whether women in Sweden choses self-employment as a way of balancing work and family commitments. Instead, it seems more plausible that women who choses self-employment while the children are young in fact are women with strong preferences for market work.

In addition to analyzing time-use data I also look at differences in number of days of parental leave taken by self-employed and wage earners. We find that the group of self-employed appears to be heterogeneous; self-employed mothers are more likely to take no, or very short, parental leave even when the children are very young but among those who do take some parental leave, self-employed mothers take on average more days of parental leave than wage-earning mothers.

This paper makes several contributions to the existing literature. First, results presented in previous research are mainly based on data from Anglo-Saxon countries while this study uses data for Sweden. The Swedish labor market is organized in a very different way than in AngloSaxon countries and it is of great interest to see if the results for Sweden are consistent with findings for other countries. One exception to previous research is Rønsen (2014) for Norway 
but this study is interesting for comparison. Second, in the present study I use register data for the period 2004-2008 covering the whole Swedish population. Most previous studies are based on rather small samples, are often restricted to smaller groups e.g. married white women, and cover earlier time periods. Third, I try to explain the association between self-employment and the presence of young children in the household by relating our findings to what is known about how self-employed and wage earners divide their time between market and household work and to differences in days of parental leave between self-employed and wage-earners.

The remainder of the paper is structured as follows. In section two I go through previous research in more detail, in section three the structure of the Swedish labor market is discussed in more detail, in section four I describe the data, variables and the econometric approach, in section five the results are presented and interpreted, in section six I relate the findings to what is known about differences in time spent on market work between self-employed and wage-earners and in section seven I analyze whether there are differences in the use of parental leave between self-employed and wage-earners, and finally section eight summarizes and concludes the paper.

\section{Previous research}

\subsection{Self-employment and work and family commitments}

In this section, results from previous studies concerning self-employment as a way of balancing work and family commitments are summarized.

Using data from the U.S., Wellington (2006) examines the hypothesis that married women are increasingly choosing self-employment as a strategy to balance family and career. In the econometric analysis, the author estimates the effect of children on the probability of being, and becoming, self-employed. This is estimated both using cross sectional and longitudinal data. It is found that the presence of young children increases the probability of being self-employed but the impact of children does not appear to have increased over time. The conclusion that is drawn is that mother's increased labor force participation comes at a direct cost of time spent with children.

Lombard (2001) uses similar data and also finds that the presence of children increases the likelihood of self-employment. Here it is assumed that women with children have a higher demand for flexible scheduling and that this is more easily attained when being self-employed. 
In an article from 1996, Boden hypothesize that fertility, defined as having at least one child under the age of six, will have a positive impact on self-employment entry. This article uses the same type of data as the two abovementioned, the Current Population Survey (CPS) for the US. Boden finds a positive influence of fertility of female self-employment.

Budig (2006) differentiate between non-professional and non-managerial self-employment on the one hand and professional and managerial self-employment on the other hand when analyzing the effects of family structure on self-employment. This is tested using survey data (the NLYS) for the US and it is found that children increases women's non-professional selfemployment but has no effect on professional self-employment. The interpretation suggested for these results is that the demand for increased flexibility and more control over work schedules is lower among women in professional wage employment since many occupations of this type already offer more flexibility. An alternative explanation is that women in professional wage employment have less family responsibilities, having fewer children compared to women in nonprofessional employment could be a sign of this.

Noseleit (2014) analyzes the relation between fertility and self-employment using data from the European Social Survey. The focus of this article is on the direction of causality between selfemployment and fertility, something that many previous studies have failed to account for. Most studies are interested in the effect of fertility, or the presence of children, on self-employment. But one could also argue that the direction of causality is reversed, i.e. that self-employment will cause women, and perhaps also men, to have more children. One argument for this is that selfemployed individuals want to maximize the probability that one of their children can take over the business and therefore have more children than employees (Broussard et al. 2013). To establish the direction of causality, Noseleit (2014) uses instrument variable techniques and instrument fertility by parents' preferences for a mixed sibling-sex composition, as has been done by Angrist and Evans (1998) and by instrumenting self-employment with the regional share of employees working in small businesses. The IV-estimates indicate that fertility has a positive effect on self-employment while he finds no evidence of that the reverse should be true, i.e. that self-employment leads to higher fertility rates among women. An exception is, however, that he finds that among women between 31 and 45 years of age, self-employment has a positive effect on fertility. 
Hundley (2000) analyzes male/female earnings differentials in self-employment using survey data from the US. He argues that organizational employment is constrained by both lower bounds (on acceptable employee contribution) and upper bounds (on employee rewards) which self-employment is not. If there are changes in the demands for household production associated with marriage and children, self-employed women could respond to these changes more easily than organizational employed women since there is no lower bound on employee contribution for the self-employed. However, this might of course result in lower incomes for the selfemployed woman. In more general terms, he argues that due to the lack of constraints for the self-employed it is likely that some self-employed will participate more intensively in either household or market work. As a consequence, self-employed married women will work fewer market hours and more housework hours and self-employed men will work more market hours and fewer housework hours compared to organizational employed women and men.

This prediction is consistent with what is found in studies using time-use data: self-employed women tend to spend less time on market work than wage earning women and more time on household work and/or child care (see Gurley-Calvez et al. 2009 for the US; Craig et al. 2014 for Australia). A study for Spain find differences in time spent on market work where self-employed women spend less time, but do not find any significant difference in the time spent on child care between self-employed and wage-earning women (Gimenez-Nadal et al. 2012 for Spain). It has also been found that self-employed women more often work during non-standard work hours, i.e. during evenings and weekends (Gimenez-Nadal et al. 2012; Lombard 2001).

These results are, however, not entirely consistent with what has been found for Sweden. Mångs (2012) finds that self-employed women, with and without young children (0-3 years) spend more hours on market work than wage-earning women. Öun and Johansson Sevä (2014) find that self-employed women with employees spend more time on market work compared to both selfemployed without employees and regularly employed women. They also find that self-employed women without employees are more likely than regularly employed to state that they experience balance between family and work commitments, while self-employed with employees are less likely of experiencing work-family balance and more likely of experiencing work to family conflict. As is shown below, a majority of self-employed females in the entire workforce have no employees and also in the sample used in Öun and Johansson Sevä (2014), the majority has no employees. 
Using data from the European Social Survey, Nordenmark et al. (2012) find that self-employed women experience a significantly higher level of work-life balance than wage-earning women while self-employed men experience a similar level of work-life balance as employed men. These are interesting results but since they use data for all 26 countries included in the survey we do not know whether the correlations are found in all countries or whether the pattern in Sweden differs from those in other European countries.

\section{Female employment in the Swedish labor market}

In this section some features of the Swedish labor market that speak against the hypothesis that women chose self-employment as a way of balancing work and family commitments are discussed. The implications of the Swedish, or Nordic, welfare state model for female labor force participation have been studied extensively (e.g. Datta Gupta et al. 2008; Ferrarini et al. 2014). Female labor force participation rates in Sweden are among the highest in the world. In 2010, 83.1 percent of Swedish women 25-64 years of age participated in the labor force compared to the OECD average of 66.2 (OECD, 2012). The high female labor force participation means that dual-earner families are very common in Sweden. Large scale public child care is an important explanation for the structure of the Swedish labor market. During recent years, parents have also come to share the parental leave period more equally between them although women still take the majority of the parental leave period. But in spite of that Swedish parents appear to divide both market work and household work more equally than parents in many other countries, previous research find that women in Sweden are not less likely than women in other countries to experience work-family conflicts. This is believed to be partly explained by the high female labor force participation (Grönlund and Öun 2010). The female labor force participation is high but the share of women working part-time is also high. Data from Eurostat for 2009 shows that slightly over 40 percent work part-time. Working part-time while the children are young would be one way of facilitating the combination of work and family commitments. Instead of leaving the labor force altogether while the children are young, many women choose to work part-time. According to the parental insurance law, employers cannot decline parents the possibility to work part-time up until the child is eight years old (Föräldraledighetslagen 1995:584). Looking 
at the time trend in part-time work we see, however, that there has been a decline in the share of women working part-time in Sweden (Wennemo Lanninger and Sundström 2014).

Partly thanks to the generous welfare system, Swedish women can choose to combine labor force participation with high fertility rates. In 2009, Eurostat estimates that the total fertility rate of Swedish women is 1.94 children. This can be compared with the average in EU (EU28) which is 1.6 children per women. Iceland has highest fertility rates (2.23) while Hungary, Portugal and Germany have lowest fertility rates $(1.32,1.34$, and 1.36).

The Swedish parental leave system is both very generous and rather flexible. For each child, the parents are assigned 480 days. During 390 days, the replacement rate is about 80 percent of their previous earnings up to a certain ceiling. During the remaining 90 days the parents receive a fixed smaller amount. The parents can divide the number of days as they please but 60 days are assigned to each of the parent individually and cannot be transferred to the other parent. Each week one can be on parental for a maximum of seven days but if one chooses for example five days the length of the total parental leave period will be longer. It is possible to combine work with parental leave. One could for example work three days a week and be on parental leave for two days.

As was mentioned in the introduction, female self-employment in Sweden is lower than in many other countries. However, female self-employment has grown in Sweden since the mid 1970`s, a development shared with many other western countries. ${ }^{2}$ Figure 1 shows the development of the number of self-employed women in Sweden based on information from the Labor force survey. Since 1970, there has been a rapid decline in the number of so called "helpers". This has traditionally been unpaid family members that have assisted in their husbands firms, most of them in farming. During the same period there has been an equally rapid increase in the number of actual self-employed women, from 40,000 in 1970 to about 100,000 in $2004 .^{3}$ This corresponds approximately to that 5 percent of all employed women are working as selfemployed.

\footnotetext{
${ }^{2}$ See Devine (1994) for an analysis of female self-employment in the U.S.

${ }^{3}$ From 2005 and onwards, Statistics Sweden does not report the number of self-employed and the number of helpers separately, but only the total number of self-employed. The number of helpers is very low so the main part of the total number of self-employed are self-employed.
} 
These four stylized facts: high female labor force participation, high share of women working part-time, high fertility rates and a low share of self-employed females suggest that women on the Swedish labor market combine market work and family formation without choosing selfemployment to a very high extent. These facts are based on data for the whole grown-up population. Below we take a closer look at the relationship between self-employment and fertility using detailed micro data for the whole Swedish population.

There are certainly other macro level factors which influence the self-employment rate in a country and may explain country differences. Since also male self-employment rates in Sweden are lower than in many other countries this suggests that (other) institutions also matters. The OECD looks for example at the correlations between self-employment (excluding agriculture) and per capita GDP and finds a negative correlation: the richer the country, the lower the selfemployment share (OECD 2011). The empirical literature has also shown that there is negative correlation between the size of the public sector and self-employment rates (Torrini 2005). The role of taxes for self-employment has been studied extensively and the general idea is that higher taxes encourage self-employment since it is easier to evade taxes if self-employed. Studies for Sweden do, however, find a negative correlation between taxes and self-employment (Davis and Henrekson 1999; Fölster 2002). The correlation between unemployment and self-employment has also been studied but the results vary. Blanchflower (2000) finds, for example, that there is a negative correlation between the unemployment rate and the self-employment rate in most countries.

\section{[FIGURE 1 ABOUT HERE]}

\section{Data and econometric analysis}

\subsection{Data and variables}

The main analysis presented in this paper is based on individual level register data from the employment register at Statistics Sweden covering the period from 2004 to 2008. This data is collected mainly for administrative purposes and includes information on for example employment status (wage-earners, self-employed or not employed) in November each year, age, marital status, number of children residing in the household, education, country of birth and place of residence. An individual is defined as self-employed with an unincorporated firm if the 
largest source of income during November is from self-employment. The self-employment income is however adjusted with the factor 1.6 since the self-employed in general report lower incomes. Self-employed with incorporated firms receive a wage income, just as regular employees, since they are employed in their own firm. The self-employed, as they are defined here, could both be owners of unincorporated or incorporated firms and of firms both with and without employees. The incorporated firms included are, however, only firms with ten or fewer stockholders. The firms can be active in all industries and include everything from farmers or carpenters to lawyers and physical therapists. In the regression analysis I can control for industry but not for occupation since the register at Statistics Sweden lacks reliable information on occupation for the self-employed.

In the analysis I restrict the sample to only include women who participate in the labor force, i.e. the dependent variable is one if an individual is working as self-employed and zero if the individual is working as a wage-earner. Individuals who are students, unemployed, on sick-leave, or outside the labor force are not included in the study. The reason for applying this restriction, which is also done in Rønsen (2014), is that we are mainly interested in how the presence of children affects occupational choices, given that one has chosen to participate in the labor force.

The main independent variable of interest in this study is a measure of fertility, or the presence of children in the household. The register includes information on the number of children in different age ranges living in the household, i.e. I do not know the exact age of the children. There are several ways of controlling for the number and the age of the children in the regression analysis. Different definitions have been tried but the main results are invariant to the definition used. I choose to present the results from a regression where we control of the number of children in all different age ranges: 0-3 years, 4-6 years, 7-10 years, 11-15 years, 16-17 years, and 18 years or above.

To be able to better understand and interpret our results on the relationship between children in different age ranges and self-employment I also present some descriptive results using aggregate data from the Harmonized European Time Use Survey (HETUS). This data was collected within a project supported by Eurostat and it is possible to calculate user defined, comparable statistical 
tables on the organization and activities of everyday life in fifteen European countries. ${ }^{4}$ The Swedish data originates from the time use survey conducted by Statistics Sweden in 2000/01.

To further illustrate the question of how self-employed and wage earners divide their time between market and household work I also use individual level data from the Swedish Level of Living Survey for year 2000. This is data from a survey that has been conducted among a random sample of 1/1000 of the Swedish population. The respondents are asked questions about their living conditions in several areas. The drawback of this data is that it includes very few selfemployed women.

\subsection{Econometric analysis}

I use panel data for the period 2004-2008 and estimate both pooled cross sectional models (eq. 1) and models that include individual time fixed effects (eq. 2). Our key independent variables of interest are the number of children living in the household in different age ranges (0-3 years, 4-6 years, 7-10 years, 11-15 years, 16-17 years, and 18 years or above). The vector $\mathrm{X}$ includes controls for: age, age squared, being married, education, industry, country of birth, county of residence and year. The regressions are estimated separately for women and men and I focus on the result for women.

$S E_{i t}=\alpha+\beta_{1}$ Child0_3 $3_{i t}+\beta_{2}$ Child4 $6_{-} 6_{i t}+\cdots+\beta_{6}$ Child $18_{i t}+\delta X_{i t}+\varepsilon_{i t}$

It should be stressed that the $\beta$-coefficients in equation 1 are not measures of the causal effect of the number of children on self-employment. In this model the comparison is made between individuals who differs in their preferences for the number of children and self-employment, two factors that are outcomes of decisions that are not exogenous to each other. To try do address this problem I include individual fixed effects in equation 2 . This is assumed to be a time fixed effect that varies between individuals but is constant over time, which for example could be preferences for employment form and family formation or family size. Since this model is estimated using panel data methods the comparison becomes intra-personal rather than interpersonal, i.e. I compare the same individual with herself over time. Put simply, I estimate the impact of a change in the number of children in different age ranges on the change on employment status to and from self-employment. More formally, I estimate the model specified

\footnotetext{
${ }^{4}$ To read more about HETUS see, https://www.h2.scb.se/tus/tus/.
} 
in equation 3 where all variables are expressed as the value of the variable for individual $i$ at time $t$ and its deviation from the mean calculated over all years for this individual.

$$
\begin{aligned}
& S E_{i t}=\alpha+\beta_{1} \text { Child0_3 } 3_{i t}+\beta_{2} \text { Child4_6 } 6_{i t}+\cdots+\beta_{6} \text { Child } 18_{i t}+\delta X_{i t}+\mu_{i}+\varepsilon_{i t} \\
& S E_{i t}-\overline{S E_{i}}=\alpha+\beta_{1}\left(\text { Child0_3 }_{i t}-\overline{\text { Child } 0 \__{i}}\right)+\beta_{2}\left(\text { Child }_{-} 6_{i t}-\overline{\text { Child }_{-} 6_{i}}\right)+\cdots+\beta_{6}\left({\text { Child } 18_{i t}-}^{-}\right. \\
& \left.\overline{\operatorname{Child} 18_{i}}\right)+\delta\left(X_{i t}-\overline{X_{i}}\right)+\left(\varepsilon_{i t}-\overline{\varepsilon_{i}}\right)
\end{aligned}
$$

The dependent variable is a dichotomous variable taking the value one if the individual is selfemployed and zero if the individual is a wage-earner. The models are first estimated using a linear probability model. This has the advantage that the interpretation of the coefficients is simple: each additional child in a certain age range increases or decreases the probability of being self-employed by a certain percentage point. Using this model there is, however, a risk that it will yield predicted probabilities outside the range of zero to one. For this reason I also estimate both pooled cross sectional and panel regressions using the non-linear logit model. To account for individual fixed effects in the logit model I estimate so called conditional fixed effects models (Chamberlain 1980, 1984; Maddala 1987). In this model, I condition on that there has been a change in the dependent variable between two time periods. Individuals who do not change state between two time periods are not included in the regressions, since they do not contribute to the likelihood function (Maddala 1987). As a consequence, this model uses substantially fewer observations than the other models.

\subsection{Descriptive statistics}

The main purpose of this study is to estimate the effect of the presence of children in the household on the probability of being self-employed. As a descriptive exercise self-employment rates among different groups of employed women are presented in Table 1. The sample is divided into eight groups depending on whether there live any children in the household, the age of the women and the age of the children. The first group includes women younger than 42 and with no children living in their household. This group presumably includes some women who have not yet had any children and where some of them will have children in the future. The last 
group also includes women with no children living in their household but who are older than 42 . This group includes women that have older children that do not live with their parents. The groups in between are not mutually exclusive since women can have children in different age spans. For example, a woman can have one child in the age range 0 to 3 and one child in the age range 4 to 6 . Previous research has found a positive correlation between age and the probability of being self-employed. There is also likely a positive correlation between the age of a woman and the age of her children. This makes it difficult to disentangle the impact of age on the selfemployment probability and the impact of the presence of children in different age ranges. This will be dealt with more carefully in the regression analysis. However, it can still be interesting to look at the correlations between self-employment, total and divided into unincorporated firms and incorporated firms, and the presence of children in the household. Self-employment is lowest among women younger than 42 years with no children and highest among women with no children but who are older than 42 . For women with children up to 17 years there appears to be an inverted $\mathrm{u}$-shaped relation between the age of the children and self-employment with a peak in the self-employment rate among mothers with children between 7 and 10 years.

In Table 2 some descriptive statistics for the groups of self-employed and wage-earning women that are included in the sample in 2008 are presented. Self-employed women are on average almost eight years older than wage-earning women. This correlation between age and selfemployment has been found in many previous studies (see for example Blanchflower 2000). The age difference is reflected in differences in marriage rates and fertility rates when studying the whole group of self-employed women; a substantially higher share of self-employed women are married and they have fewer children in all age groups living in their household. A higher share among the self-employed have relatively low education, not more than upper secondary school, while a lower share have university education. I also present the distribution over sector which tend to be very different among wage-earners and self-employed. The largest group of wageearning women is employed in the health care sector, 27 percent, while only 7 percent of the self-employed are active in this sector. We also find the same pattern regarding the educational sector. The self-employed are instead predominately located within "personal and cultural services" and "financial and business services". Lastly, annual labor income, both excluding and including transfers, are presented and we find that the self-employed on average have lower incomes than wage-earners. 
[TABLE $1 \& 2$ ABOUT HERE]

\section{Results}

The results from our estimations of the relation between the presence of children in the household and the probability of being self-employed are presented in Table 3. In general, there is a positive correlation between the number of children in the household, in all age ranges except 16-17 years, and self-employment. It can be assumed that family responsibilities and perhaps foremost, the workload in the household associated with having children, decreases as the children gets older. An implication of this would be that the demand for self-employment also decreases with the age of the children. Our results suggest that this is indeed the case. According to the estimations based on the pooled cross sectional data an additional child in the age range $0-3$ increases the self-employment probability by 0.49 percentage points while an additional child in the age range 4-6 years increases the self-employment probability by 0.31 percentage points. The logit model show a similar pattern; the odds ratio of being self-employed is more positively affected by an additional child in the younger age groups than in older age groups and the odds ratio of being self-employed decreases for children aged from 16 to 17.

The cross sectional models cannot be used to identify the causal effect of young children on selfemployment. The more relevant question is if the arrival of young children in the household and hence an increased demand for labor market flexibility increases the likelihood of mothers switching from wage employment to self-employment. To address this question we use of the panel dimension of the data and estimate fixed effect models. The point estimates of these models are smaller than in the cross-sectional models but we still find a positive effect of more young children in the household on self-employment. The conditional fixed-effect logit model only uses observations for which there is a change in the dependent variable, i.e. individuals who change from wage employment to self-employment (a positive outcome) and individuals who change from self-employment to wage employment (a negative outcome). Here, only the estimate for the youngest age group is positive and significant. In this very restrictive model there is a positive effect of an additional young child on the probability of becoming selfemployed, i.e. switching from wage employment to self-employment. 
We have also estimated the same models for men. These results are presented in Table A1 in the Appendix. We find a positive correlation between the number of young children and the probability of being self-employed also for men. However, the impact of an additional child is smaller if the children are very young (0-3 years) and stronger if the children are older. For women, we find that the impact of an additional child decrease by the age of the children. This could mean that fathers do not choose self-employment when the need to be caring for the children is the highest which seems to be the case for mothers.

[TABLE 3 ABOUT HERE]

\subsection{Heterogeneous effects by educational level}

It has been argued in previous studies (see e.g. Hundely 2000) that professionals and workers in managerial positions would not need to choose self-employment in order to achieve this type of flexibility but that many wage-earning jobs in the modern labor market also are flexible with respect to where and when the work is performed. This idea is tested by conducting the analysis separately by three educational groups; (1) primary school or upper secondary 2 years or less, (2) Upper secondary more than 2 years or higher education less than 3 years and (3) Higher education 3 years or more or post-graduate education. We would expect to find most professionals and workers in managerial positions in the group with the highest educational level and hence expect the effect of children on self-employment to be non-existent or at least weakest in this group. The results are presented in Table 4 and from the linear probability model we find that the association between the number of young children and self-employment probabilities is strongest among women with the lowest educational level. ${ }^{5}$ However, even for women with the highest level of education, each additional child in the youngest age group has a positive and significant impact on the probability of being self-employed. In the fixed effects regressions the estimates of children in the youngest age group are about the same for all educational groups. Hence, it does not appear to be the case that only low educated women choose self-employment as an alternative employment form while the children are young.

\section{[TABLE 4 ABOUT HERE]}

\footnotetext{
${ }^{5}$ These models have also been estimated using a logit model but the results are not presented her but are available from the author upon request. The main results are invariant to the choice of model.
} 


\subsection{Interpreting the results}

The results presented in the previous section suggest that self-employment among women increases with the number of children and that the effect is decreasing in the age of the children. This is consistent with the results presented in previous studies and supports the hypothesis that women with more child care, and hence in many cases more household responsibilities, more likely chose self-employment than other groups of women. In previous studies similar results have been interpreted as evidence of that this group of women has a higher demand for flexible scheduling and chooses self-employment as a way to achieve it. This interpretation is supported by the findings in studies using time-use data who report that self-employed women spend more time on household work and less time on market work than wage-earning women do. But is this the way the results should be interpreted for Sweden? In the remaining sections of the paper I try to shed some light on two possible explanations for our results. The first hypothesis is that women in Sweden, in spite of the institutions in place on the labor market with the purpose of facilitating the combination of work and family commitments, also chooses self-employment as a way of balancing work and family. The second hypothesis, which has been given far less attention in self-employment literature, is that mothers of young children who choose selfemployment in fact are women who have very strong preferences for market work. Selfemployment could be a way for these women to avoid reducing time spent on market work to the same extent as they would have done if they would have been employed as wage-earners when they have young children. Self-employment is assumed to satisfy the demand for flexibility and instead of working eight hours straight from morning to afternoon as one often does when being an employee, self-employed parents could work while the children are in day care or in school, pick up them in the afternoon and spend time with them and doing household choirs and then continue to work in the evening when the partner has come home and can take over child care responsibilities.

For the self-employed there could also be the possibility to work while the child is very young and has not started day care yet. As was mentioned before, the parental leave system in Sweden is generous and flexible allowing parents, while they are on parental leave, to work during some days of the week although not receiving any benefits during this time. But children under the age of one are not covered by the public child care system so if neither of the parents can care for these very young children it is up to the family to find private alternatives, like a grandmother or 
a paid nanny. However, to have employed nannies is still not very common in Sweden. If one were self-employed prior to having a child, it could be difficult to be away from the business full time for up to a year and if there are no employees in the firm, it might be difficult for the firm to survive. There is lots of anecdotal evidence of self-employed women who continue to work just after the baby is born or take a very short period of parental leave.

A second motivation for why self-employment might be chosen by women with strong preferences for market work is that even though Sweden in many respects is a gender equal country there is still a non-negligible gender wage gap which is larger higher up in the wage distribution (Albrecht et al 2003). One of the main explanations that has been put forward is that women still take the majority of parental leave days and that the parental leave period in many cases are very long, up to one and a half year. Young women are often aware of that there is a risk of being punished in the labor market if they stay away from the labor market for a long period when they have children. But at the same time there is still a social pressure on women that they should stay at home and take care of the children. Becoming self-employed could then be a way of achieving both these goals: to still be active on the labor market when the children are very young and also be the one taking the main responsibility for caring of the child. There are a limited number of wage-earning jobs where this is possible.

We will not be able to fully separate between these two possible explanations; choosing selfemployment to better balance work and family commitments or choosing self-employment in order to still be active on the labor market when the children are young, but to be able to say something I use two different indicators: time-use data for Sweden and information from administrative registers about the number of days of parental leave. If women choose selfemployment as a way of balancing work and family commitments we would expect them to spend less time on market work and more time on household work compared to wage-earning women. We also would expect them to take more days of parental leave. On the other hand, if it is women with strong preferences for market work that chose self-employment while the children are young we would expect the opposite: they spend more time on market work and less time on household work compared to wage-earning women and they will take fewer days of parental leave compared to wage-earners. 
One caveat to this analysis is that I do not have micro data on the time use of the individuals in the administrative data that I use to estimate self-employment probabilities. We will therefore rely on some secondary sources with information on the time-use of the self-employed and a regression analysis of a sample that includes only a small number of self-employed women (the Swedish Level-of-Living Survey).

\section{Time use among self-employed men and women in Sweden}

Previous studies for the US, Australia and Spain reveal that self-employed women spend less time on market work than wage-earning women. Descriptive statistics from the Harmonized European Time Use Survey also show that in most countries wage earning women spend more time on market work than self-employed women. See Figure 2. According to this data, this is also the case in Sweden but the difference is smaller than in most other countries.

\section{[FIGURE 2 ABOUT HERE]}

The evidence on time-use of self-employed men and women in Sweden are scarce but at least two studies report that self-employed women spend more, or as much, time on market work as wage-earning women. Average weekly hours of market work based on different data sources are summarized in Table 5. Mångs (2013) report that self-employed women with children 0-3 years of age spend on average 37.8 hours per week on market work and wage-earning women spend 35.9 hours per week on market work. These results are based on a survey and the sample of selfemployed is strongly selected since those having an annual income below 100,000 SEK are excluded and so are combiners, i.e. self-employed who also have had an income from wage employment during the year. Johansson Sevä and Öun (2014) report that self-employed women with employees spend on average 45.8 hours per week on market work and wage-earning women spend on average 38.3 hours on market work. Self-employed women without employees spend about the same time on market work as wage-earning women. From the Swedish Level of Living survey in 2000 we also see that self-employed women spend more time on market work than wage-earning women. The sample of self-employed women is however small in this survey and the average weekly working time is only based on 84 individuals. Data for Sweden from the Harmonized European time use survey show that self-employed women spend slightly less time on market work but the difference, 1.4 hours/week, is smaller than in many other countries 
(https://www.h2.scb.se/tus/tus/). For men, all data sources show that self-employed men spend more time on market work than wage-earning men.

In previous studies it has also been found that self-employed women spend more time on household work than wage-earning women. The existing evidence for Sweden reveals that there are small differences in time spent on household work between wage-earning and self-employed women. Again, the Harmonized European Time Use Survey show that in most countries selfemployed women spend substantially more time on household work than wage earning women do. But the differences are small in Sweden. See Figure 3. In Table 5 we have also summarized what is known about time spent on household work based on data for Sweden. Even though the descriptive statistics on time spend on market work and household work presented here in no way are conclusive, it could still be argued that it is not apparent that Swedish women choose self-employment when the children are young to spend less time on market work and more time on household responsibilities.

\section{[FIGURE 3 \& TABLE 5 ABOUT HERE]}

Using individual data from the Level of Living Survey for year 2000 I perform a multivariate analysis of time spent on market and household work, the results are presented in Table 6. Even though there are few individuals, in particular women, who are self-employed in this data we still find significant differences regarding time spent on market work: self-employed women spend on average about six hours more on market work than wage-earning women. We also find that self-employed both with and without employees spend more time on market work than wageearning women but the differences are larger between wage-earners and self-employed with employees. We find no significant differences with respect to time spent on housework. The pattern for men is very similar: the self-employed spend more time on market work than wageearners. Here we do, however, also find that self-employed men, in particular those without employees, spend significantly less time on household work than wage-earning men.

It is also interesting to note that the employment status of the partner has a significant impact on the time spent on market work. For both women and men, having a self-employed spouse decreases the time spent on market work by about 1.4 hours for women and by almost 3 hours per week for men. Having a self-employed spouse increases the time spent on household work for women, but for men it has no significant effect on time spent on household work. 
[TABLE 6 ABOUT HERE]

\section{Parental leave among wage-earners and self-employed}

As mentioned before, the parental leave system in Sweden is generous and flexible allowing parents, while they are on parental leave, to work during some days of the week although not receiving any benefits during this time. Being self-employed it could be difficult to be away from the business full time for up to a year. In particular if there are no employees in the firm, it might be difficult for the firm to survive.

One way to analyze if the self-employed tend to work more while the children are very young is to study differences in days of parental leave. Here the same register data is used as was used in the main analysis and information on total number of days of parental leave during the year is used. A drawback of this data is that I do not have information about when during the year the parental leave days were used. To be able to compare self-employed and wage earners I need to assume that the distribution of child births across the year is the same for wage-earners and selfemployed since the total number of days taken during a year will depend on when the children are born. If a child is born on January $1^{\text {st }}$ it is possible for the parents to have 365 days of parental leave during the year while if the child is born on December $31^{\text {st }}$, one could have one, or possibly zero, days of parental leave. Second, doing this exercise I restrict the sample to only include the births of the first child, i.e. I condition the sample on that there are no children living in the household in period $t-1$ while there is at least one child aged 0-3 living in the household in period $t$. Here the groups of self-employed are divided into those with an unincorporated firm and those with an incorporated firm. The former group is treated as self-employed in the social security system while the latter group is treated as employees since they are employed in their own firm. Looking at sample means for the three groups: wage-earners, self-employed with an unincorporated firm and self-employed with an incorporated firm, we find that the difference between the groups in average number of days of parental leave are small but there is a larger spread in the number of days among self-employed with an unincorporated firm. Drawing histograms for the distribution of number of days in parental leave where each bin are 30 days, it is clear that the share among self-employed (with an unincorporated firm) who takes 30 days or less are higher compared to the other groups (see Figure 3). 
To investigate this further, a number of different regressions have been estimated. In the first one we look at the association between self-employment and the probability of taking zero days of parental leave conditional on that there were no children living in the household in period $t-1$ and that there is at least one child in the age range 0 to 3 years in period $t$. In most cases, this means that the women have become a (biological) mother but there could also be other situations. For example, if a woman has no children of her own in period $t-1$ and then marry a spouse who has children of his/her own this would appear in the data as the women have had a child although it is not her biological child. This is not likely to be very common and we have no reason to believe that it is more common among self-employed women than among wage-earning women. In either case, this would be a situation where it is natural that the woman does not take any days of parental leave. In the second regression I estimate the probability of taking less than 30 days of parental leave, in the third regression the dependent variable is total net days of parental leave during a year and in the fourth regression I use the same dependent variable but I now exclude all those who have zero days of parental leave.

The results of the regression analysis are presented in Table 7 and focusing on self-employed with unincorporated firms, we see that self-employed women have a 4.6 percentage points higher probability of taking zero days of parental leave during the year and a 3.3 percentage points higher probability of taking less than 30 days of parental leave. The third specification shows that there is no significant difference in net number of days of parental leave during the year but when all women who take zero days of parental leave are excluded (column four) we find that self-employed take almost five more days of parental leave than wage-earners do.

These results suggest that the group of self-employed is very heterogeneous; some take no or very few days of parental leave while others take more than the average wage-earner. To be able to say something more about the determinants of the number of days of parental leave I have estimated a separate equation for the self-employed controlling for some variables that are specific to the self-employed: corporate form, number of employees, industry and selfemployment income one year prior to having a child. ${ }^{6}$ Surprisingly, we find that very few of the included variables are significantly different from zero neither when the outcome is the probability of taking zero days of parental leave nor when the dependent variable is net days of

\footnotetext{
${ }^{6}$ The results are not presented here but are available from the author upon request.
} 
parental leave. Corporate form, number of employees, age, number of children 0-3 years, marital status and country of birth (not shown) do not contribute to explain the variation in the amount of parental leave taken. The only variable which seems to be important is education. The probability of taking zero days of parental leave increases with the level of education while the number of days decreases with educational level. There are some differences between industries where those in agriculture and financial services are more likely of taking zero days of parental leave compared to those whose business are within "personal and cultural services". An additional variable that seems to be important is labor earnings in the previous period; a higher income is correlated with a lower probability of taking zero days and an increase in the number of days. This could mean that self-employed with lower earnings simply cannot afford to take as much parental leave as a self-employed with higher earnings.

[TABLE 7 ABOUT HERE]

[FIGURE 3 ABOUT HERE]

\section{Summary and conclusions}

Previous studies have found a positive correlation between the presence of children in the household and self-employment probabilities among women. This has been interpreted as evidence of that women might choose self-employment as a way of balancing work and family commitments. Related studies using time-use data find that self-employed women spend more time on household work than wage earning women and less time on market work.

There are reasons to believe that Swedish women do not choose self-employment in order to achieve more flexibility and to facilitate the combination of work and family. There are several institutions in place in the Swedish labor market with the purpose of facilitating the combination of work and family for parents of young children: generous parental leave system, easy access to public child care, and the right of parents to work part-time until the child turns eight. Also the fact that mothers and fathers share childcare and household responsibilities more equally than in many other countries suggests that mothers (and fathers) of young children might not have a very high demand for self-employment, at least not as way of balancing work and family commitments. 
The results presented in this paper do, however, point towards that mothers of young children who are active on the Swedish labor market are more likely to choose self-employment than other groups of women. This result is also found in panel data models where I control for unobserved individual heterogeneity, i.e. when I take into account that those who choose selfemployment might differ from wage-earners in some systematic way regarding preferences for family formation and family size. I find evidence of mothers with young children being more likely of choosing self-employment than other groups of women. From time-use data I find that self-employed women spend as much, or more, time on market work than wage-earning women. This result differs from what has been found for other countries. From analyzing parental leave use among wage-earners and self-employed, I conclude that the group of self-employed appears to be heterogeneous; self-employed mothers are more likely to take no, or very short, parental leave even when the children are very young but among those who do take some parental leave, self-employed mothers take on average more days of parental leave than wage-earning mothers.

The Swedish government wants to increase self-employment among women mainly as a part of the general policy of increasing self-employment and business creation. The start-up and growth of new business is often considered to be a driving force behind economic growth. But if women become self-employed to meet the increasing family demand for child care and household responsibilities and as a consequence spend less time on market work and more time on household work, this is a development which is likely to go against the idea of Sweden moving towards an even more gender equal country. It has been argued that if women choses selfemployment for this reason it is likely to reinforce traditional gender roles in the household and in the labor market (Craig et al. 2012). We have not found any indications of that Swedish women chose self-employment to reduce time spend on market work or to be a modern form of housewife, although these cases might exist. On the contrary, our results rather point towards that women who have strong preferences for market chose self-employment as a way of organizing their parental leave period in a different way than what Swedish mothers usually do.

The main focus of this paper has not been to establish causality between the number, or the presence, of children in the household and self-employment. However, since panel data is available and the sample is large we estimate panel data models to control for unobserved heterogeneity across individuals to try to estimate the relationship between children and selfemployment as accurately as possible given the data at hand. I recognize that there might be a 
problem of reversed causality, i.e. that self-employment affects fertility, and I believe that this is an important question that is on the agenda over questions for future research. It is, however, reassuring that Noseleit (2014) who uses an instrumental variable approach only finds evidence of there being a causal relationship between fertility and self-employment and not the other way around. 


\section{Tables and Figures}

Figure 1 Number of self-employed women (100's) in Sweden 1970-2013

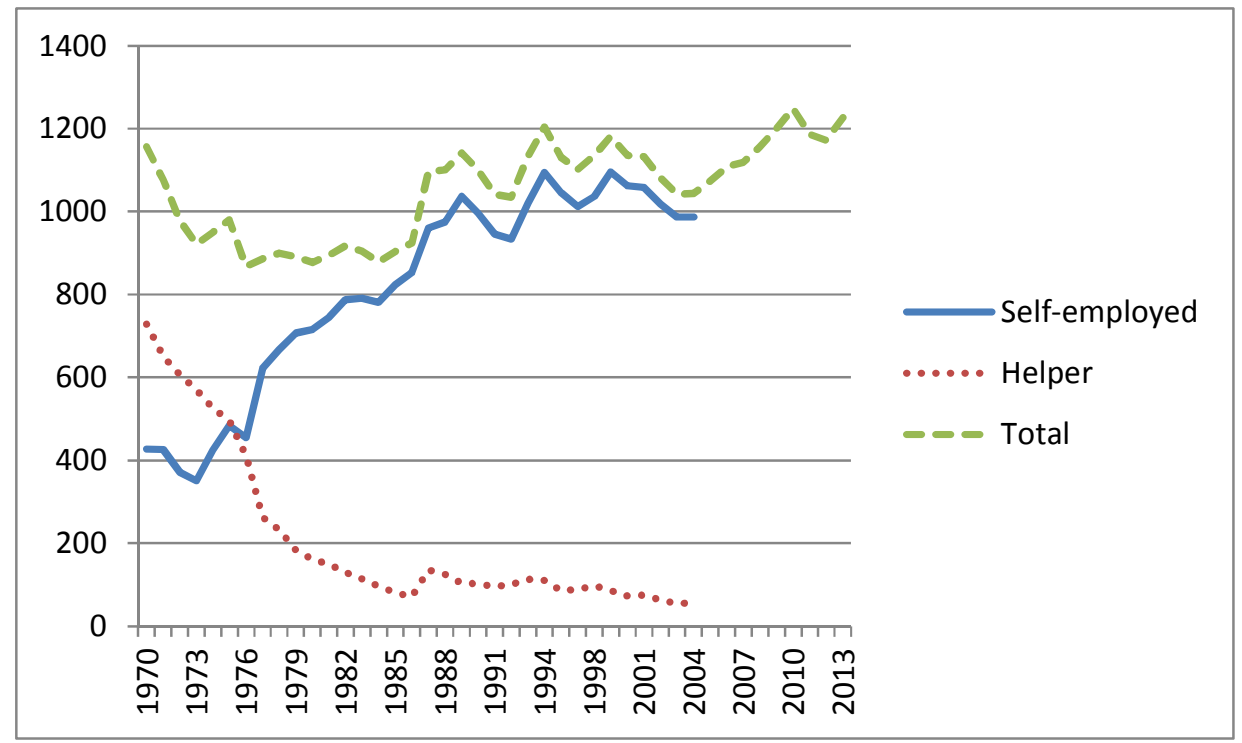

Source: Labor force survey (Statistics Sweden).

Table 1 Self-employment rate (\%) and age of the children in the household 2008, women

\begin{tabular}{|c|c|c|c|}
\hline & Self-employed (total) & $\begin{array}{c}\text { Unincorporated } \\
\text { firm }\end{array}$ & Incorporated firm \\
\hline $\begin{array}{l}\text { No children (in the household) } \\
\text { and younger than } 42\end{array}$ & 2.5 & 2.0 & 0.5 \\
\hline Children $0-3$ years & 4.0 & 3.1 & 0.9 \\
\hline Children 4-6 years & 4.6 & 3.5 & 1.1 \\
\hline Children 7-10 years & 5.0 & 3.6 & 1.4 \\
\hline Children $11-15$ years & 4.9 & 3.5 & 1.4 \\
\hline Children 16-17 years & 3.9 & 2.7 & 1.2 \\
\hline Children above 18 & 4.3 & 3.1 & 1.2 \\
\hline $\begin{array}{l}\text { No children (in the household) } \\
\text { and older than } 42\end{array}$ & 7.0 & 5.3 & 1.8 \\
\hline
\end{tabular}


Table 2 Descriptive statistics, selected variables 2008

\begin{tabular}{|c|c|c|}
\hline & Wage-earners & Self-employed \\
\hline Age (Std. Dev) & $\begin{array}{c}39.9 \\
(13.7)\end{array}$ & $\begin{array}{c}47.1 \\
(11.1)\end{array}$ \\
\hline Married & 40.8 & 58.3 \\
\hline \multicolumn{3}{|l|}{ Number of children: } \\
\hline Total & 1.071 & 1.004 \\
\hline $0-3$ years & 0.15 & 0.13 \\
\hline 4-6 years & 0.11 & 0.11 \\
\hline $7-10$ years & 0.14 & 0.15 \\
\hline $11-15$ years & 0.22 & 0.23 \\
\hline $16-17$ years & 0.14 & 0.11 \\
\hline above 18 & 0.32 & 0.26 \\
\hline \multicolumn{3}{|l|}{ Education (\%) } \\
\hline \multicolumn{3}{|l|}{ Primary school less than 9 years } \\
\hline Primary school $9(10)$ years & 11.8 & 10.0 \\
\hline Upper secondary 2 years or less & 22.3 & 26.0 \\
\hline Upper secondary more than 2 years & 23.1 & 23.9 \\
\hline Higher education less than 3 years & 15.6 & 15.7 \\
\hline Higher education 3 years or more & 23.6 & 19.2 \\
\hline Post graduate education & 0.7 & 0.5 \\
\hline Missing information & 0.4 & 0.5 \\
\hline \multicolumn{3}{|l|}{ Industry $(\%)^{a}$} \\
\hline Unknown & 1.5 & 11.3 \\
\hline Agriculture & 7.6 & 7.2 \\
\hline Manufacturing & 0.5 & 4.4 \\
\hline Construction & 1.1 & 1.8 \\
\hline Retailing and communication & 11.7 & 14.8 \\
\hline Financial and business services & 13.5 & 21.2 \\
\hline Education & 15.9 & 2.3 \\
\hline Health care & 27.4 & 7.4 \\
\hline Personal and cultural services & 4.6 & 21.3 \\
\hline Total annual labor income (SEK) & 210,056 & 164,610 \\
\hline $\begin{array}{l}\text { Total annual labor income (inkl. } \\
\text { transfers) (SEK) }\end{array}$ & 221,400 & 172,21 \\
\hline Number of observations & $2,304,762$ & 114,840 \\
\hline
\end{tabular}

a The industries "production of energy" and "public administration" are not shown due to a smaller share than 0.1 percent of self-employed. 
Table 3 Probability of self-employment among employed women, 2004-2008

\begin{tabular}{lcccc}
\hline & $\begin{array}{c}\text { Pooled cross } \\
\text { sections }\end{array}$ & Panel data & $\begin{array}{c}\text { Pooled cross } \\
\text { sections }\end{array}$ & Panel data \\
& $\begin{array}{c}\text { Linear } \\
\text { probability } \\
\text { model }\end{array}$ & $\begin{array}{c}\text { Linear } \\
\text { probability } \\
\text { model with } \\
\text { individual } \\
\text { fixed effects }\end{array}$ & $\begin{array}{c}\text { Logit model } \\
\text { (odds ratios) }\end{array}$ & $\begin{array}{c}\text { Conditional } \\
\text { fixed-effects } \\
\text { logit model } \\
\text { (odds ratios) }\end{array}$ \\
\hline Number of children: & & & & \\
0-3 years & $0.0049 * * *$ & $0.0017 * * *$ & $1.2033 * * *$ & $1.1215^{* * * *}$ \\
& $(0.00015)$ & $(0.00015)$ & $(0.00503)$ & $(0.01879)$ \\
4-6 years & $0.0031 * * *$ & $0.0007 * * *$ & $1.1154 * * *$ & 1.0307 \\
& $(0.00018)$ & $(0.00017)$ & $(0.00527)$ & $(0.01924)$ \\
7-10 years & $0.0027 * * *$ & $0.0007 * * *$ & $1.0877 * * *$ & 1.0271 \\
11-15 years & $(0.00016)$ & $(0.00015)$ & $(0.00414)$ & $(0.01795)$ \\
16-17 years & $0.0007 * * *$ & $0.0004 * * *$ & $1.0263 * * *$ & 1.0057 \\
18 plus & $(0.00012)$ & $(0.00013)$ & $(0.00301)$ & $(0.01533)$ \\
& $-0.0062 * * *$ & $-0.0011 * * *$ & $0.9320 * * *$ & $0.9365 * * *$ \\
Observations & $(0.00017)$ & $(0.00013)$ & $(0.00442)$ & $(0.01566)$ \\
R-squared & $0.0002 * *$ & -0.0000 & 0.9956 & $0.9515^{* * *}$ \\
\hline
\end{tabular}

Notes: The cross-sectional model includes controls for: age, age squared, married, education, industry (11 groups), country of birth (11 groups), county of residence (21) and year (5 years). The panel data models do not include controls for year and country of birth. 
Table 4 Probability of self-employment among employed women, 2004-2008. Heterogeneous effects by education

Primary school or upper secondary 2 years or less
Upper secondary more than 2 years or higher education less than 3
Higher education 3 years or more or post-graduate education

years

\begin{tabular}{lcccccc}
\hline & $\begin{array}{c}\text { Linear } \\
\text { probability } \\
\text { model }\end{array}$ & $\begin{array}{c}\text { Linear } \\
\text { probability } \\
\text { model with } \\
\text { individual } \\
\text { fixed } \\
\text { effects }\end{array}$ & $\begin{array}{c}\text { Linear } \\
\text { probability } \\
\text { model }\end{array}$ & $\begin{array}{c}\text { Linear } \\
\text { probability } \\
\text { model with } \\
\text { individual } \\
\text { fixed } \\
\text { effects }\end{array}$ & $\begin{array}{c}\text { Linear } \\
\text { probability } \\
\text { model }\end{array}$ & $\begin{array}{c}\text { Linear } \\
\text { probability } \\
\text { model with } \\
\text { individual } \\
\text { fixed } \\
\text { effects }\end{array}$ \\
\hline Number of & & & & & \\
children: & & & & & & \\
\hline 0-3 years & $0.0104 * * *$ & $0.0016^{* * *}$ & $0.0053 * * *$ & $0.0018 * * *$ & $0.0050 * * *$ & $0.0019 * * *$ \\
& $(0.00033)$ & $(0.00031)$ & $(0.00024)$ & $(0.00024)$ & $(0.00023)$ & $(0.00026)$ \\
4-6 years & $0.0067 * * *$ & $0.0018^{* * *}$ & $0.0027 * * *$ & $0.0007 * * *$ & $0.0045 * * *$ & 0.0004 \\
& $(0.00034)$ & $(0.00032)$ & $(0.00030)$ & $(0.00028)$ & $(0.00032)$ & $(0.00034)$ \\
7-10 years & $0.0044 * * *$ & $0.0011 * * *$ & $0.0029 * * *$ & $0.0011 * * *$ & $0.0039 * * *$ & $0.0011 * * *$ \\
& $(0.00026)$ & $(0.00027)$ & $(0.00026)$ & $(0.00026)$ & $(0.00031)$ & $(0.00035)$ \\
11-15 years & $0.0010 * * *$ & $0.0004 * *$ & $0.0007 * * *$ & $0.0011 * * *$ & $0.0025 * * *$ & $0.0009 * * *$ \\
& $(0.00018)$ & $(0.00021)$ & $(0.00021)$ & $(0.00022)$ & $(0.00027)$ & $(0.00032)$ \\
16-17 years & $-0.0093 * * *$ & $-0.0017 * * *$ & $-0.0016 * * *$ & 0.0001 & $0.0024 * * *$ & 0.0004 \\
& $(0.00024)$ & $(0.00021)$ & $(0.00032)$ & $(0.00024)$ & $(0.00046)$ & $(0.00036)$ \\
18 plus & $0.0016 * * *$ & $0.0004 * * *$ & $-0.0015 * * *$ & $-0.0003 *$ & $0.0007 * * *$ & -0.0000 \\
& $(0.00017)$ & $(0.00016)$ & $(0.00016)$ & $(0.00015)$ & $(0.00026)$ & $(0.00025)$ \\
\hline Observations & $4,624,021$ & $4,624,021$ & $4,492,838$ & $4,492,838$ & $2,667,299$ & $2,667,299$ \\
R-squared & 0.141 & 0.049 & 0.102 & 0.033 & 0.098 & 0.049 \\
\hline
\end{tabular}

Notes: The cross-sectional model includes controls for: age, age squared, married, education, industry (11 groups), country of birth (11 groups), county of residence (21) and year (5 years). The panel data models do not include controls for year and country of birth. 
Figure 2 Time spent during an ordinary work day on market work

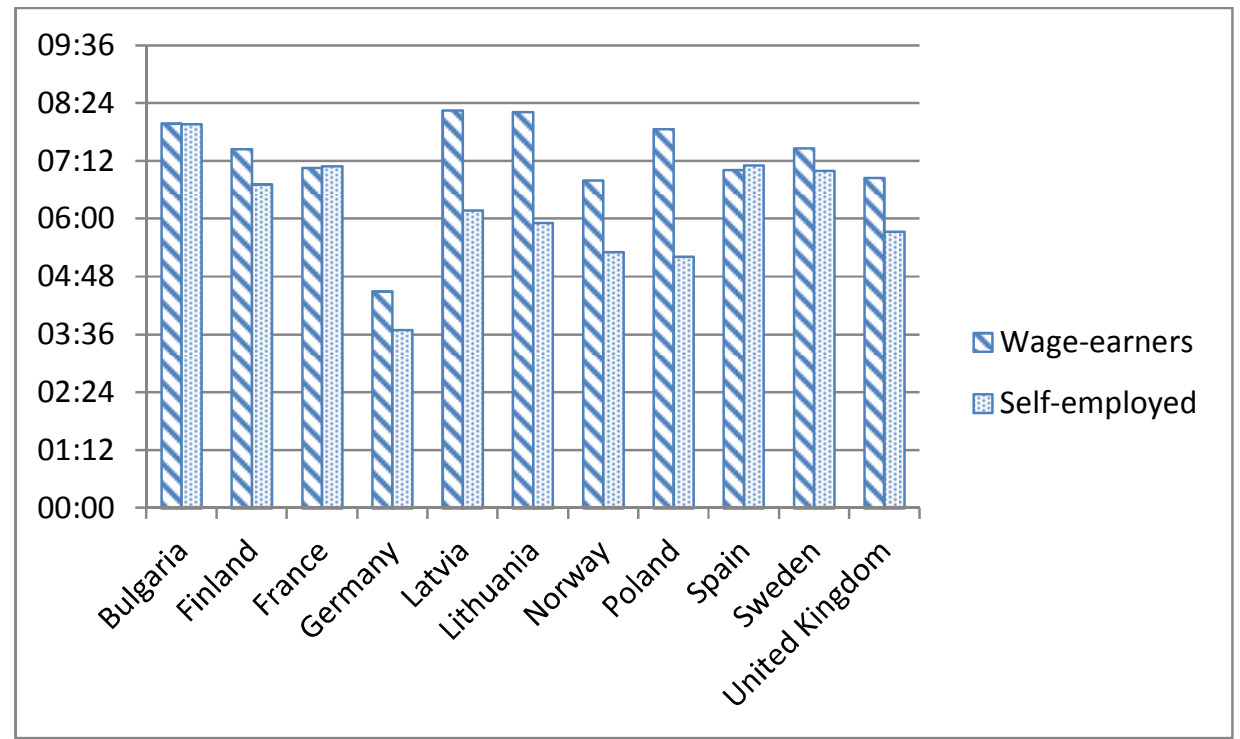

Source: The Harmonized European Time Use Survey

Figure 3 Time spent during an ordinary work day on household work

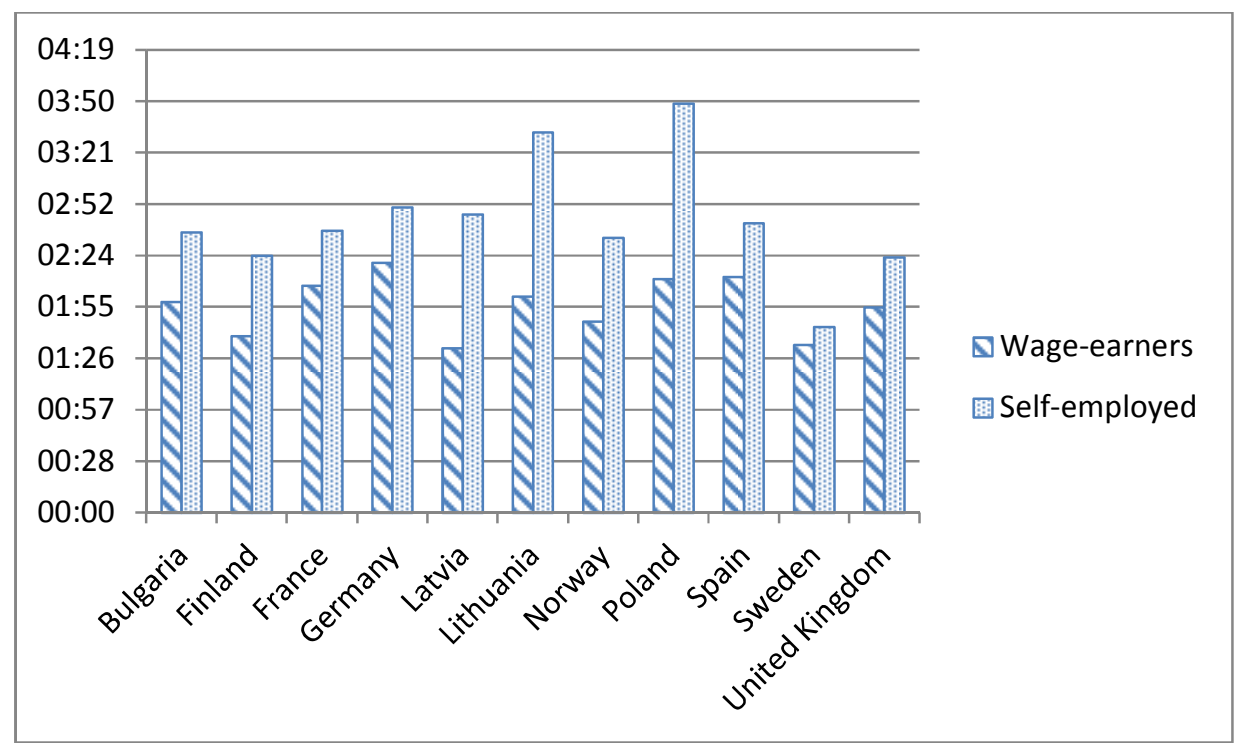

Source: The Harmonized European Time Use Survey 
Table 5 Summary of descriptive results of time spend on market and household work

\begin{tabular}{|c|c|c|c|c|}
\hline & \multicolumn{4}{|c|}{ Women } \\
\hline & $\begin{array}{c}\text { Self- } \\
\text { employed } \\
\text { Total }\end{array}$ & $\begin{array}{c}\text { Self- } \\
\text { employed } \\
\text { without } \\
\text { employees }\end{array}$ & $\begin{array}{c}\text { Self- } \\
\text { employed } \\
\text { without } \\
\text { employees }\end{array}$ & $\begin{array}{l}\text { Wage- } \\
\text { earners }\end{array}$ \\
\hline \multicolumn{5}{|l|}{ Hours of market work } \\
\hline $\begin{array}{l}\text { Mångs (2013) (women with } \\
\text { children } 0-3 \text { years) }\end{array}$ & 37.8 & - & - & 35.9 \\
\hline Johansson Sevä and Öun (2014) & - & 38.6 & 45.8 & 38.3 \\
\hline $\begin{array}{l}\text { Level of Living Survey } 2000 \\
\text { (own calculations) }\end{array}$ & 41.1 & - & - & 35.8 \\
\hline $\begin{array}{l}\text { Harmonized European time use } \\
\text { survey }^{\mathrm{a}} \text { (own cacluations) }\end{array}$ & 35.0 & - & - & 36.4 \\
\hline \multicolumn{5}{|l|}{ Hours of household work } \\
\hline $\begin{array}{l}\text { Mångs (2013) (women with } \\
\text { children 0-3 years) }\end{array}$ & 12.1 & - & - & 13.2 \\
\hline $\begin{array}{l}\text { Level of Living Survey } 2000 \\
\text { (own calculations) }\end{array}$ & 14.9 & - & - & 14.8 \\
\hline \multirow[t]{3}{*}{$\begin{array}{l}\text { Harmonized European time use } \\
\text { survey }^{\text {a }} \text { (own cacluations) }\end{array}$} & $1.44 \mathrm{~h} /$ day & & & $1.34 \mathrm{~h} / \mathrm{day}$ \\
\hline & \multicolumn{4}{|c|}{ Men } \\
\hline & $\begin{array}{c}\text { Self- } \\
\text { employed } \\
\text { Total }\end{array}$ & $\begin{array}{c}\text { Self- } \\
\text { employed } \\
\text { without } \\
\text { employees }\end{array}$ & $\begin{array}{c}\text { Self- } \\
\text { employed } \\
\text { without } \\
\text { employees }\end{array}$ & $\begin{array}{l}\text { Wage- } \\
\text { earners }\end{array}$ \\
\hline \multicolumn{5}{|l|}{ Hours of market work } \\
\hline $\begin{array}{l}\text { Mångs (2013) (men with } \\
\text { children } 0-3 \text { years) }\end{array}$ & 44.6 & & & 41.1 \\
\hline Johansson Sevä and Öun (2014) & - & 45.4 & 50.8 & 42.8 \\
\hline $\begin{array}{l}\text { Level of Living Survey } 2000 \\
\text { (own calculations) }\end{array}$ & 49.6 & - & - & 39.4 \\
\hline $\begin{array}{l}\text { Harmonized European time use } \\
\text { survey }^{\mathrm{a}} \text { (own cacluations) }\end{array}$ & 42.1 & & & 40.7 \\
\hline \multicolumn{5}{|l|}{ Hours of household work } \\
\hline $\begin{array}{l}\text { Mångs (2013) (women with } \\
\text { children 0-3 years) }\end{array}$ & 9.1 & - & - & 10.0 \\
\hline $\begin{array}{l}\text { Level of Living Survey } 2000 \\
\text { (own calculations) }\end{array}$ & 5.5 & - & - & 6.8 \\
\hline $\begin{array}{l}\text { Harmonized European time use } \\
\text { survey }^{\mathrm{a}} \text { (own cacluations) }\end{array}$ & $0.44 \mathrm{~h} /$ day & - & - & $0.52 \mathrm{~h} / \mathrm{day}$ \\
\hline
\end{tabular}


Table 6 Regression analyzes for time spent on market and household work, Level of Living survey 2000, women.

\begin{tabular}{|c|c|c|c|c|}
\hline WOMEN & $\begin{array}{c}\text { Hours of } \\
\text { market work }\end{array}$ & $\begin{array}{c}\text { Hours of } \\
\text { market work }\end{array}$ & $\begin{array}{c}\text { Hours of } \\
\text { housework }\end{array}$ & $\begin{array}{c}\text { Hours of } \\
\text { housework }\end{array}$ \\
\hline Wage-earner & Ref. & Ref. & Ref. & Ref. \\
\hline Self-employed, all & $\begin{array}{c}6.078 * * * \\
(1.483)\end{array}$ & - & $\begin{array}{l}-0.960 \\
(0.941)\end{array}$ & - \\
\hline $\begin{array}{l}\text { Self-employed, } \\
\text { without employees }\end{array}$ & - & $\begin{array}{c}4.959 * * \\
(2.023)\end{array}$ & - & $\begin{array}{l}-1.478 \\
(1.280)\end{array}$ \\
\hline $\begin{array}{l}\text { Self-employed, } \\
\text { with employees }\end{array}$ & - & $\begin{array}{l}7.334 * * * \\
(2.143)\end{array}$ & - & $\begin{array}{l}-0.424 \\
(1.295)\end{array}$ \\
\hline Partner wage-earner & Ref. & Ref. & Ref. & Ref. \\
\hline Partner self- employed & $\begin{array}{c}-1.412 * * \\
(0.670)\end{array}$ & $\begin{array}{c}-1.446 * * \\
(0.676)\end{array}$ & $\begin{array}{c}2.013 * * * \\
(0.677)\end{array}$ & $\begin{array}{c}1.995 * * * \\
(0.678)\end{array}$ \\
\hline Partner other status & $\begin{array}{l}-0.497 \\
(0.680)\end{array}$ & $\begin{array}{l}-0.505 \\
(0.681)\end{array}$ & $\begin{array}{c}-2.088 * * * \\
(0.748)\end{array}$ & $\begin{array}{c}-2.091 * * * \\
(0.748)\end{array}$ \\
\hline Constant & $\begin{array}{l}38.311 * * * \\
(1.092)\end{array}$ & $\begin{array}{c}38.328 * * * \\
(1.089)\end{array}$ & $\begin{array}{c}11.225 * * * \\
(1.134)\end{array}$ & $\begin{array}{c}11.244 * * * \\
(1.133)\end{array}$ \\
\hline $\begin{array}{l}\text { Observations } \\
\text { R-squared }\end{array}$ & $\begin{array}{l}1,556 \\
0.097 \\
\end{array}$ & $\begin{array}{l}1,556 \\
0.098 \\
\end{array}$ & $\begin{array}{l}1,318 \\
0.140 \\
\end{array}$ & $\begin{array}{l}1,318 \\
0.141 \\
\end{array}$ \\
\hline MEN & $\begin{array}{c}\text { Hours of } \\
\text { market work }\end{array}$ & $\begin{array}{c}\text { Hours of } \\
\text { market work }\end{array}$ & $\begin{array}{c}\text { Hours of } \\
\text { housework }\end{array}$ & $\begin{array}{c}\text { Hours of } \\
\text { housework }\end{array}$ \\
\hline $\begin{array}{l}\text { Wage-earner } \\
\text { Self-employed, all }\end{array}$ & $\begin{array}{l}10.520 * * * \\
(0.923)\end{array}$ & - & $\begin{array}{c}-1.290 * * * \\
(0.417)\end{array}$ & - \\
\hline $\begin{array}{l}\text { Self-employed, } \\
\text { without employees }\end{array}$ & - & $\begin{array}{c}8.403 * * * \\
(1.526)\end{array}$ & - & $\begin{array}{c}-1.946 * * * \\
(0.514)\end{array}$ \\
\hline $\begin{array}{l}\text { Self-employed, } \\
\text { with employees }\end{array}$ & - & $\begin{array}{l}12.402 * * * \\
(1.032)\end{array}$ & - & $\begin{array}{l}-0.728 \\
(0.595)\end{array}$ \\
\hline \multicolumn{5}{|l|}{ Partner wage-earner } \\
\hline Partner self- employed & $\begin{array}{c}-2.979 * * \\
(1.353)\end{array}$ & $\begin{array}{c}-2.710 * * \\
(1.335)\end{array}$ & $\begin{array}{c}0.170 \\
(0.666)\end{array}$ & $\begin{array}{l}0.257 \\
(0.661)\end{array}$ \\
\hline Partner other status & $\begin{array}{l}-0.540 \\
(0.431)\end{array}$ & $\begin{array}{l}-0.580 \\
(0.425)\end{array}$ & $\begin{array}{l}-0.050 \\
(0.308)\end{array}$ & $\begin{array}{l}-0.063 \\
(0.308)\end{array}$ \\
\hline Constant & $\begin{array}{c}40.627 * * * \\
(0.702)\end{array}$ & $\begin{array}{c}40.735^{* * * *} \\
(0.695)\end{array}$ & $\begin{array}{c}6.686 * * * \\
(0.791)\end{array}$ & $\begin{array}{c}6.744 * * * \\
(0.793)\end{array}$ \\
\hline Observations & 1,764 & 1,764 & 1,398 & 1,398 \\
\hline R-squared & 0.232 & 0.241 & 0.074 & 0.076 \\
\hline
\end{tabular}

Note: All models include controls for: number of young children (0-9 years), having a partner (married/cohabitating), age, education, and region. Robust standard errors in parentheses $* * * \mathrm{p}<0.01, * * \mathrm{p}<0.05, * \mathrm{p}<0.1$ 
Figure 3 Distribution of days of parental leave

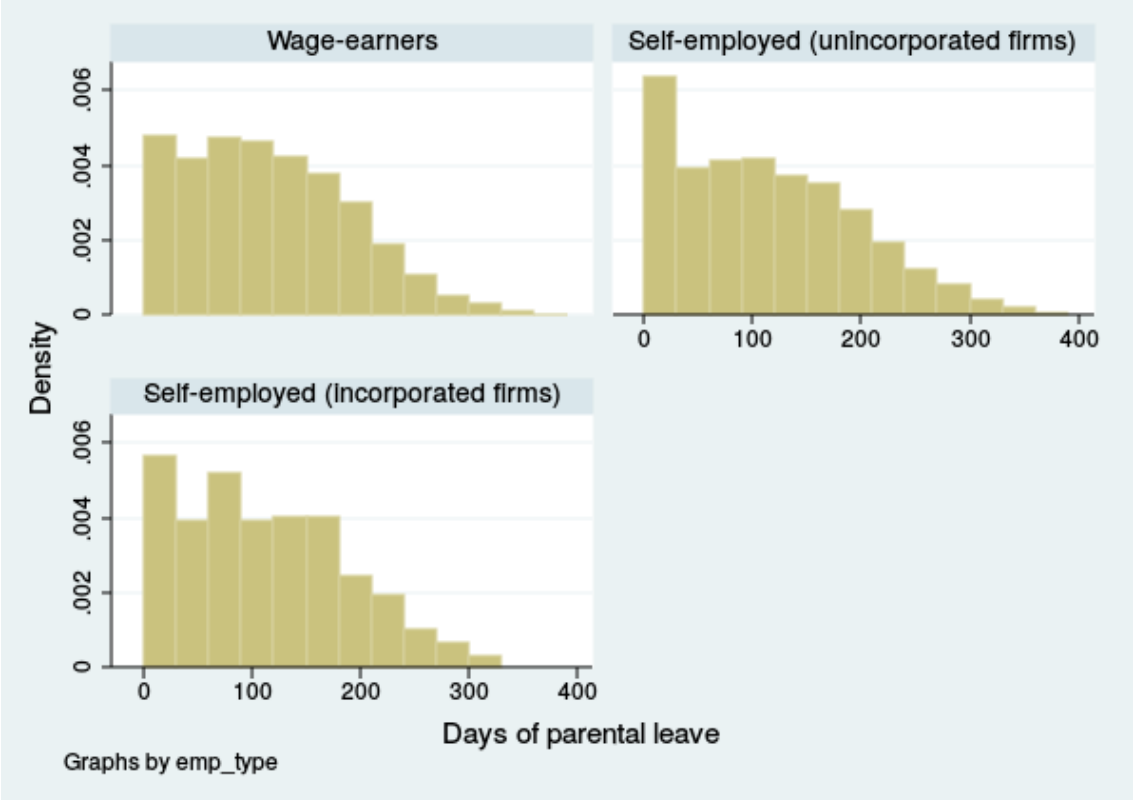

Table 7 Days of parental leave for women with no children in the household in period $\mathrm{t}-1$ and at least one child in the age range $0-3$ in period $t$

\begin{tabular}{lcccc}
\hline & $\begin{array}{c}\text { No days of } \\
\text { parental leave }\end{array}$ & $\begin{array}{c}\text { Fewer than } 30 \\
\text { days of } \\
\text { parental leave }\end{array}$ & $\begin{array}{c}\text { Number of } \\
\text { days of } \\
\text { parental leave }\end{array}$ & $\begin{array}{c}\text { Number of } \\
\text { days of } \\
\text { parental leave } \\
\text { if greater than } \\
\text { zero }\end{array}$ \\
\hline Wage-earners & Ref. & Ref. & Ref. & Ref. \\
Self-employed & $0.0463^{* * *}$ & $0.0327^{* * *}$ & -1.3049 & $4.9650^{* * *}$ \\
(unincorporated firm) & $(0.00514)$ & $(0.00643)$ & $(1.35858)$ & $(1.33943)$ \\
Self-employed & $0.0217 * *$ & $0.0247 * *$ & -2.8761 & -0.2738 \\
(incorporated firm) & $(0.00843)$ & $(0.01165)$ & $(2.32602)$ & $(2.28654)$ \\
Additional controls & Yes & Yes & Yes & Yes \\
\hline Number of obs. & 153,254 & 153,254 & 153,254 & 144,250 \\
$\mathrm{R}^{2}$ & 0.017 & 0.009 & 0.020 & 0.022 \\
\hline
\end{tabular}

Note: All models include controls for: number of children 0-3 years, age, age squared, married, education, industry (11 groups), country of birth (11 groups), county of residence (21) and year (5 years). 


\section{References}

Albrecht, James, Anders Björklund and Susan Vroman (2003), "Is There a Glass Ceiling in Sweden", Journal of Labor Economics, Vol. 21(1), pp. 145-177.

Angrist, Joshua D. And William N. Evans (1998), “Children and their Parents' Labor Supply: Evidence from Exogenous Variations in Family Size", American Economic Review, Vol. 88(3), pp. 450-477.

Anxo, Dominique, Thomas Ericson and Andreas Mångs (2010), "Self-employment and the gender division of domestic and market work in Sweden", Mimeo, CAFO, Linnéuniversitetet.

Blanchflower, David G. (2000), "Self-employment in OECD countries", Labour Economics, Vol. 7(5), pp. 471-505.

Boden, Richard J. (1996), "Gender and Self-Employment Selection: An Empirical Assessment”, Journal of Socio-Economics, Vol. 25(6), pp. 671-682.

Boden, Richard J. (1999), "Flexible Working Hours, Family Responsibilities, and Female SelfEmployment", American Journal of Economics and Sociology, Vol. 58(1), pp. 7183.

Broussard, Nzinga H., Ralph Chami, and Gregory D. Hess (2013), “(Why) Do self-employed parents have more children?" Review of economics of the Household, DOI 10.1007/s11150-013-9190-0.

Budig, Michelle J (2006), "Intersections on the Road to Self-Employment: Gender, Family and Occupational Class", Social Forces, Vol. 84(4), pp. 2223-2239.

Carr, Deborah (1996), "Two Paths to Self-Employment? Women's and Men's Self-Employment in the United States, 1980", Work and Occupations, Vol. 23(1), pp. 26-53.

Chamberlain, Gary (1980), "Analysis of covariance with qualitative data", Review of Economic Studies Vol. 47(1), pp. 225-238.

Chamberlain, Gary (1984), Panel data. In: Griliches, Z., Intriligator, M. (Eds.), Handbook of

Econometrics, vol. 2. North-Holland, Amsterdam

Davis, Steven J. and Magnus Henrekson (1999), "Explaining national differences in the Size and industry distribution of employment”, Small Business Economics, Vol. 12(1), pp. 59-83.

Datta Gupta, Nabantia, Nina Smith and Mette Verner (2008), "The impact of Nordic countries' family friendly policies on employment, wages, and children", Review of Economics of the Household, Vol. 6(1), pp.65-89.

Devine, Theresa (1994), "Characteristics of Self-Employed Women in the United States", Monthly Labor Review, Vol. 117(3), pp. 20-34. 
Ferrarini, Tommy, Walter Korpi and Stefan Englund (2013), “Women's Opportunities under Different Family Policy Constellations: Gender, class, and Inequality Tradeoffs in Western Coutries Re-examined", Social Politics, Vol. 20(1), pp. 1-40.

Fölster, Stefan (2002), “Do lower taxes stimulate self-employment?”, Small Business Economics, Vol. 19(2), pp. 135-145.

Föräldraledighetslagen, SFS 1995:584

Gimenez-Nadal, Jose Alberto Molina, and Raquel Ortega (2012), "Self-employed mothers and the work-family conflict", Applied Economics, Vol. 44(17), pp. 2133-2147

Gurley-Calvez, Tami, Amelia Biehl, and Katherine Harper (2009), ”Time-Use Patterns and Women Entrepreneurship", American Economic Review: Papers and Proceedings, Vol. 99(2), pp. 139-144.

Hundley, Greg (2000), "Male/Female Earnings Differences in Self-Employment: The Effects of Marriage, Children, and the Household Division of Labor", Industrial and Labor Relations Review, Vol. 54(1), pp. 95-114.

Johansson Sevä, Ingemar and Ida Öun (2014), "Self-employment as a strategy to reduce workfamily conflict? The importance of Family/Lifestyle motives", unpublished work, Umeå University.

Lombard, Karen V (2001), "Female self-employment and demand for flexible, nonstandard work schedules", Economic Inquiry, Vol. 39(2), pp. 214-237

Maddala, G.S., (1987), "Limited dependent variable models using panel data", Journal of Human Resources, Vol. 22(3), pp. 307-338.

Mångs, Andreas (2013), Self-Employment in Sweden: A Gender Perspective, Linnaeus University Dissertations No 146/213, Växjö: Linnaeus University Press

Nordenmark, Mikael, Stig Vinberg and Mattias Strandh (2012), "Job control and demands, work-life balance and well-being among self-employed men and women in Europe", Vulnerable Groups \& Inclusion, Vol. 3, http://dx.doi.org/10.3402/vgi.v3i0.18896

Noseleit, Florian (2014),'Female self-employment and children", Small Business Economics, Vol. 43(3), pp. 549-569.

OECD (2012), www.stats.oecd.org. 2014-05-23

Rønsen, Marit (2014), "Children and family: A barrier or an incentive to female selfemployment in Norway”, International Labour Review, Vol. 153(2), pp. 337-349.

Torrini, Roberto (2005), "Cross-country differences in self-employment rates: the role of institutions", Labour Economics, Vol. 12(5), pp. 661-683. 
Wellington, Alison J. (2006), "Self-employment: the new solution for balancing family and career?", Labour Economics, Vol. 13(3), pp. 357-386.

Wennemo Lanninger, Alma and Marianne Sundström (2014), "Part-Time Work in the Nordic region: Part-time work, gender and economic distribution in the Nordic countries", TemaNord 2014:503, Nordic Council of Ministers. 


\section{Appendix}

Table A1 Probability of self-employment among employed men, 2004-2008

\begin{tabular}{|c|c|c|c|c|}
\hline & $\begin{array}{c}\text { Pooled cross } \\
\text { sections }\end{array}$ & Panel data & $\begin{array}{c}\text { Pooled cross } \\
\text { sections }\end{array}$ & Panel data \\
\hline & $\begin{array}{c}\text { Linear } \\
\text { probability } \\
\text { model }\end{array}$ & $\begin{array}{l}\text { Linear } \\
\text { probability } \\
\text { model with } \\
\text { individual } \\
\text { fixed effects }\end{array}$ & $\begin{array}{l}\text { Logit model } \\
\text { (relative risk } \\
\quad \text { ratios) }\end{array}$ & $\begin{array}{c}\text { Conditional } \\
\text { fixed-effects } \\
\text { logit model } \\
\text { (relative risk } \\
\text { ratios) }\end{array}$ \\
\hline \multicolumn{5}{|l|}{ Number of children: } \\
\hline $0-3$ years & $\begin{array}{l}0.0080 * * * \\
(0.00021)\end{array}$ & $\begin{array}{l}0.0010 * * * \\
(0.00019)\end{array}$ & $\begin{array}{l}1.1747 * * * \\
(0.00312)\end{array}$ & $\begin{array}{l}1.0288 * * * \\
(0.00985)\end{array}$ \\
\hline 4-6 years & $\begin{array}{c}0.0095 * * * \\
(0.00029)\end{array}$ & $\begin{array}{c}0.0025 * * * \\
(0.00022)\end{array}$ & $\begin{array}{l}1.1441 * * * \\
(0.00355)\end{array}$ & $\begin{array}{l}1.0525 * * * \\
(0.01170)\end{array}$ \\
\hline $7-10$ years & $\begin{array}{c}0.0095^{* * * *} \\
(0.00024)\end{array}$ & $\begin{array}{c}0.0030 * * * \\
(0.00021)\end{array}$ & $\begin{array}{l}1.1130 * * * \\
(0.00280)\end{array}$ & $\begin{array}{l}1.0597 * * * \\
(0.01117)\end{array}$ \\
\hline $11-15$ years & $\begin{array}{c}0.0064 * * * \\
(0.00018)\end{array}$ & $\begin{array}{c}0.0024 * * * \\
(0.00017)\end{array}$ & $\begin{array}{l}1.0583 * * * \\
(0.00206)\end{array}$ & $\begin{array}{l}1.0260 * * * \\
(0.00964)\end{array}$ \\
\hline 16-17 years & $\begin{array}{c}-0.0002 \\
(0.00027)\end{array}$ & $\begin{array}{c}0.0013 * * * \\
(0.00019)\end{array}$ & $\begin{array}{c}0.9694 * * * \\
(0.00311)\end{array}$ & $\begin{array}{l}0.9769 * * \\
(0.01078)\end{array}$ \\
\hline 18 plus & $\begin{array}{c}0.0066 * * * \\
(0.00014)\end{array}$ & $\begin{array}{c}0.0007 * * * \\
(0.00013)\end{array}$ & $\begin{array}{l}1.0512 * * * \\
(0.00191)\end{array}$ & $\begin{array}{c}0.9903 \\
(0.00776) \\
\end{array}$ \\
\hline $\begin{array}{l}\text { Observations } \\
\text { R-squared }\end{array}$ & $\begin{array}{c}12,463,133 \\
0.132\end{array}$ & $\begin{array}{c}12,463,133 \\
0.029 \\
2920303\end{array}$ & $12,463,133$ & 952,981 \\
\hline
\end{tabular}

